\title{
Article
}

Doi 10.5943/sif/1/1/12

Copyright $($ C Mushroom Research Foundation 2016

\section{Corynespora celastri sp. nov. on Celastraceae from India}

\author{
Kumar $\mathbf{S}^{1}$ and Singh $\mathbf{R}^{2}$ \\ ${ }^{1}$ Department of Forest Pathology, Kerala Forest Research Institute, Peechi 680653, Kerala, India. \\ ${ }^{2}$ Centre of Advanced Study in Botany, Institute of Science, Banaras Hindu University, Varanasi 221005, U.P., India
}

Kumar S, Singh R 2016 - Corynespora celastri sp. nov. on Celastraceae from India. Studies in Fungi 1(1), 125-129, Doi 10.5943/sif/1/1/12

\begin{abstract}
Corynespora celastri sp. nov., is introduced on living leaves of Celastrus paniculatus (Celastraceae) collected from Paniyara forest of Mahrajganj, Uttar Pradesh, India. The new species is illustrated and compared with closely similar species reported on Celastraceae. This species is characterized by having longer conidiophores and conidia among the members reported on same host family. A key to all species of Corynespora on Celastraceae is also provided.
\end{abstract}

Key words - fungal diversity - hyphomycetes - new species

\section{Introduction}

The family Celastraceae (Eudicots, Celastrales) is one of the main families of Angiosperm (flowering plants), commonly called the staff vine or bittersweet family. The family contains 96 genera and 1,350 species (Christenhusz \& Byng 2016), distributed mostly in tropical and temperate region. The plants of this family are mostly woody and shrubs. Among the family, the plant genus Celastrus (staff vine, staff tree or bittersweet) has includes 30-40 species. The host (Celastrus paniculatus Willd. - Jyotishmati) on which we described the new fungus, is a rare, endangered and economically important medicinal plant has used since ancient time in the traditional Ayurvedic system. The plant is woody climbing shrub distributed throughout India, mainly in tropical forests and subtropical Himalayas and it grows in the range of 1,800-2,000 meters. Recent studies show that the wild populations of the plant in India are at high risk (Warrier et al. 1996). The species is vulnerable in Western Ghats of South India (Rajasekharan \& Ganeshan 2002). The plant is critically endangered (CR) in Uttar Pradesh and Uttarakhand (Prakash \& Singh 2001). The plant is used as medicine in different kinds of diseases. The plant leaves contain bioactive compounds 'saponin' which responsible for anti-microbial and anti-fungal activities.

The fungus Corynespora (Corynesporascaceae) has been examined as one of the pathogen of forest plants in tropics and subtropics that causes disease on the living leaves. During our recent survey in Terai forest region (Paniyara Forest, Mahrajganj) of Uttar Pradesh for inventory of foliicolous fungi, Corynespora celastri was found hitherto undescribed on living leaves of Celastrus paniculatus (Celastraceae). Descriptions and illustration of the new taxon is presented here in details. 


\section{Materials \& Methods}

The fresh leaves with disease symptoms were collected from the Paniyara forest (subtropical forest) of Mahrajganj district of Uttar Pradesh. The collected samples were carried to the laboratory and processed by following the standard techniques (Castañeda-Ruiz 2005). The sun dried and pressed leaf specimens were placed in air tight polyethylene bags and then kept in paper envelops along with collection details. Photographs of infection spots on host leaf were taken by using Sony DSC-5730 camera. For examination of the fungal structure and spore morphology, the microscope slides were prepared in lacto-phenol cotton blue mount mixtures. The slides were examined using an Olympus BX51 microscope (Olympus, Tokyo, Japan) by using Syntek USB camera. The microphotographs were stored in electronic format TIF. Detailed observations of morphological characters were carried out at different magnification through light microscope $(200 \times$ and $400 \times)$. The measurements of 15 conidia, hila, and conidiophores with the extremes given in parentheses were done with the help of micrometer. Morphotaxonomic determinations were made with the help of current literatures. The holotype has been deposited in Ajrekar Mycological Herbarium (AMH), Agharkar Research Institute (ARI), Pune (MS), India. The systematics of the taxon is given in accordance with Ellis (1971, 1976), Cannon and Kirk (2007), Kirk et al. (2008), Seifert et al. (2011), Farr \& Rossman (2015), Jayasiri et al. (2015), the Index Fungorum (www.indexfungorum.org; accessed 30 July 2015) and Mycobank (www.mycobank.org; accessed 30 July 2015)

\section{Results}

Corynespora celastri Sham. Kumar \& Raghv. Singh, sp. nov.

Figs $1-2$ MycoBank MB 817427

FoF 02386

Etymology: the specific epithet celastri in reference to host genus.

Foliicolous, Infection spots initially hypogenous but later amphigenous, circular, subcircular to irregular, 5 to more than $20 \mathrm{~mm}$ in diameter, brown to blackish, necrotic. Colonies epiphyllous, effuse, greyish. Mycelium internal. Sexual morph: undetermined. Asexual morph: Stromata absent. Conidiophores solitary, macronematous, mononematous, cylindrical, erect to procumbent, straight to flexuous, unbranched, curved, thick-walled, smooth, 5-18-septate, with 3-8 successive cylindrical proliferations, mid brown, 135-200 × 3-5 $\mu \mathrm{m}$. Conidiogenous cells integrated, terminal, brown, smooth, monotretic, scars unthickened. Conidia acrogenous, dry, solitary, unbranched, thin-walled, smooth, straight to slightly curved, usually obclavate to obclavate-cylindrical, 7-17-distoseptate with 0-1 transverse band like eusepta, 55-120 $\times 8-15 \mu \mathrm{m}$ $(\mathrm{x}=87.5 \times 11.5 \mu \mathrm{m}, \mathrm{n}=15)$, apex obtuse to rounded, olivaceous to very light brown, hilum thickened, 3-5 $\mu \mathrm{m}$ wide, germinating conidia present.

Known distribution - India

Material examined - India, Uttar Pradesh, Mahrajganj, Paniyara Forest, on living leaves of Celastrus paniculatus Willd. (Celastraceae), $6^{\text {th }}$ November, 2014, Shambhu Kumar, AMH 9687 (holotype), BSIPMH 031 (isotype).

\section{Discussion}

Two species of Corynespora have already been reported on family Celastraceae viz. C. aterrima (Berk. \& M.A. Curtis ex Cooke) M.B. Ellis on Gymnosporia buxifolia (L.) Szyszył. (三 Celastrus buxifolius L.) (Ellis 1960) and Celastrus sp. (Ellis 1971) from Africa and C. cassicola has been also reported as endophyte on Elaeodendron glaucum (Rottb.) Pers. from the tropical forests of southern India (Murali et al. 2007). Currently C. aterrima is found synonym of Solicorynespora aterrima (Berk. \& M.A. Curtis) R.F. Castañeda \& W.B. Kendrick (1990). Below table and key can be used to distinguish our new species from other species. 

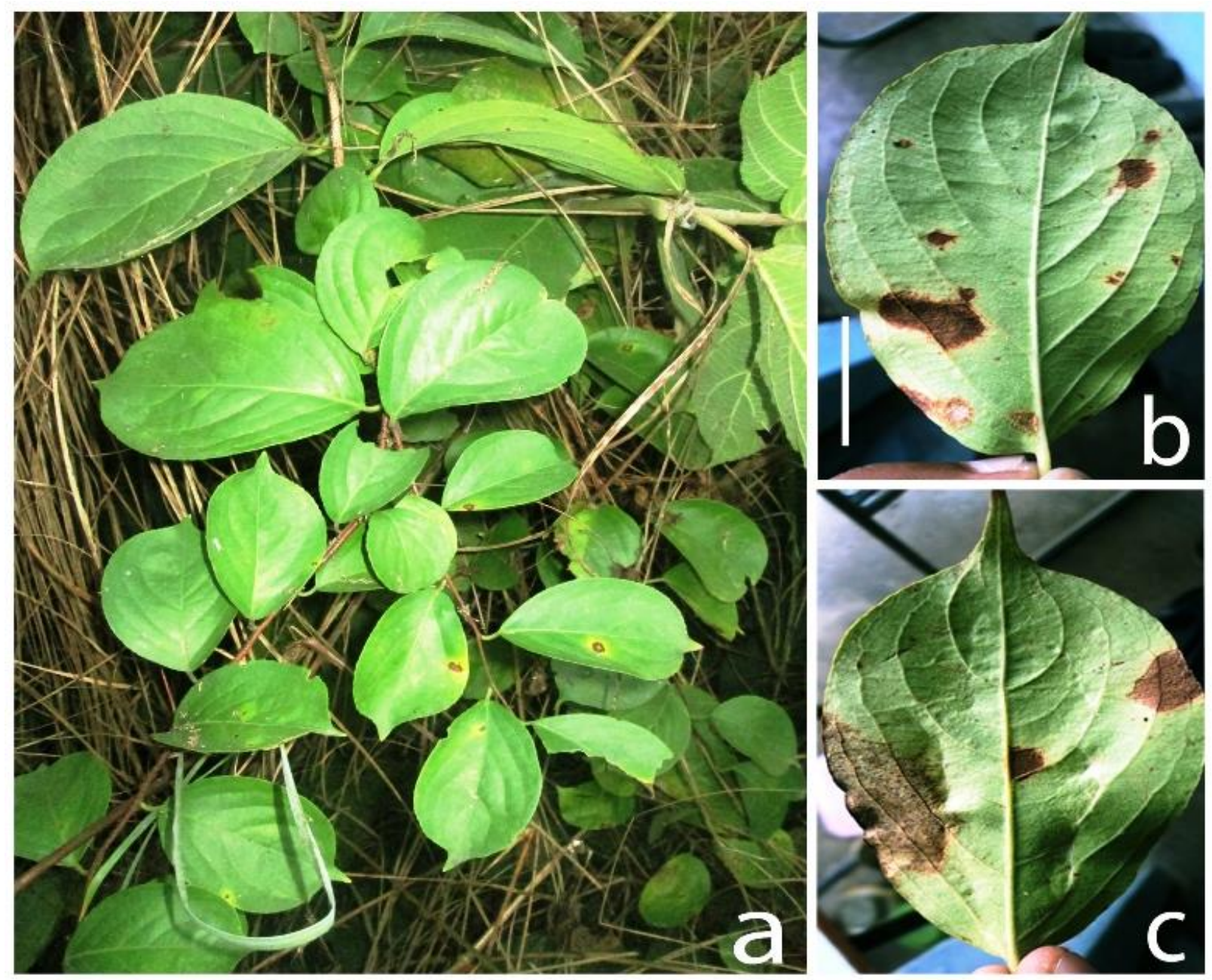

Fig. 1 - Corynespora celastri on Celastrus paniculatus. a. Host plant. b-c. Leaf spots. Scale bars = $20 \mathrm{~mm}$.

Table 1 Comparison of Corynespora spp. reported on Celastraceae

\begin{tabular}{lll}
\hline Corynespora spp. & Conidiophores & Conidia \\
\hline C. aterrima & $120-140 \times 7-10 \mu \mathrm{m}$ & $33-74 \times 8-10 \mu \mathrm{m}, 3-5$-eusepta \\
C. cassicola & $110-850 \times 4-11 \mu \mathrm{m}$ & $40-220 \times 9-22 \mu \mathrm{m}, 4-22-$ \\
C. celastri & $135-200 \times 3-5 \mu \mathrm{m}$ & $\begin{array}{l}\text { distosepta } \\
55-120 \times 8-15 \mu \mathrm{m}, 7-17- \\
\end{array}$ \\
\hline
\end{tabular}

\section{Key to all species of Corynespora on Celastraceae}

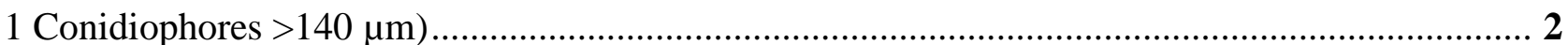

$1^{*}$ Conidiophores $\leq 140 \mu \mathrm{m}$, Conidia $33-74 \times 8-10 \mu \mathrm{m}, 3-5$-eusepta ............................ aterrima

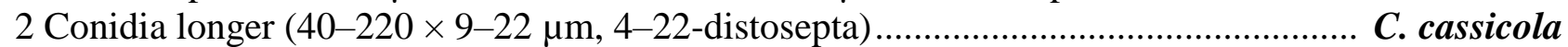

2* Conidia 55-120 × 8-15 $\mu \mathrm{m}, 7-17$-distosepta.............................................................. C. celastri 

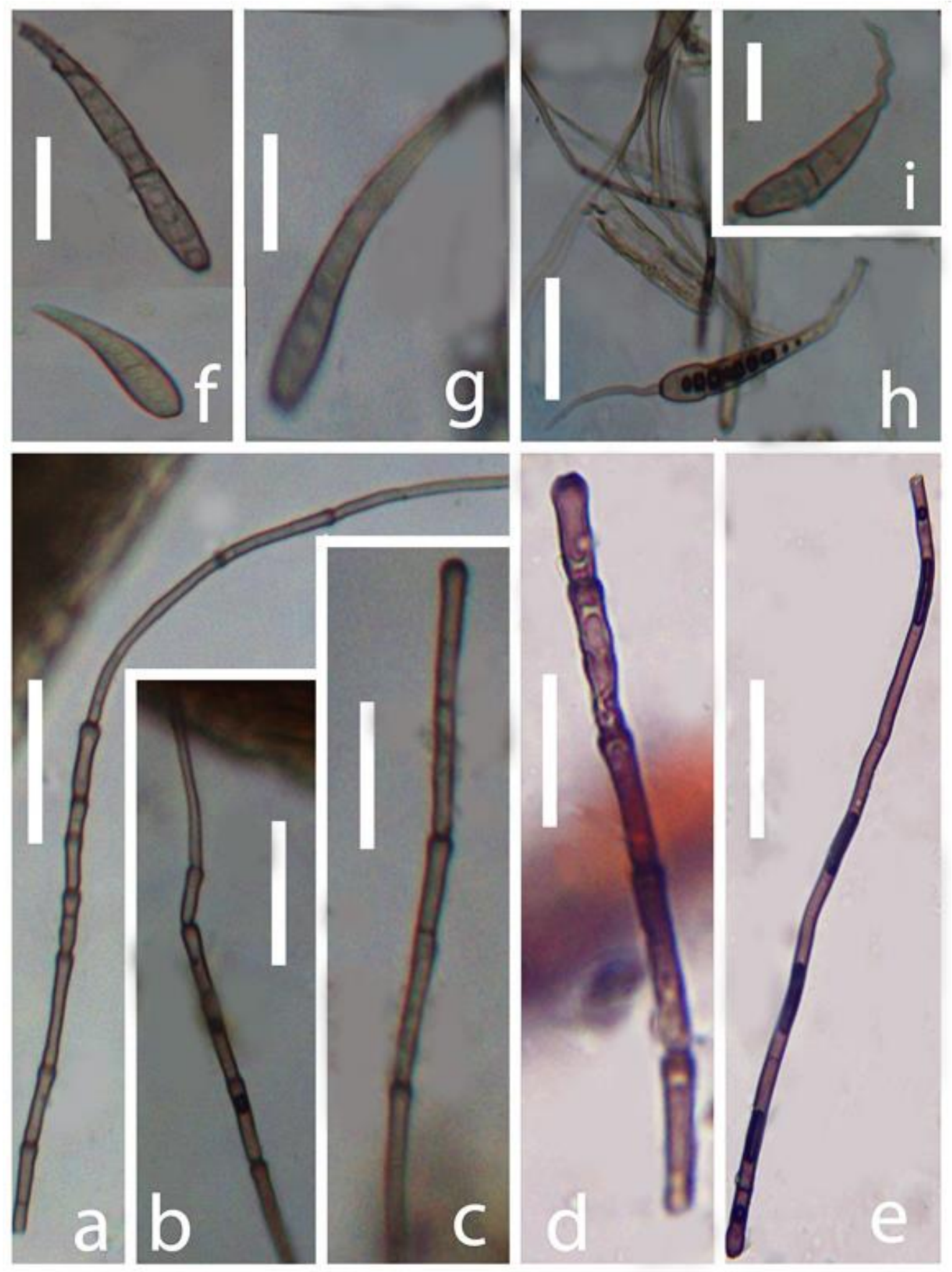

Fig. 2 - Corynespora celastri (holotype, AMH 9687). a-e. Conidiophores. f-g. Conidia. h- i. Germinating conidia. Scale bars $=20 \mu \mathrm{m}$.

\section{Acknowledgements}

The authors' express their sincere gratitude to the Director (Dr. P.G. Latha), Kerala Forest Research Institute, Peechi Kerala for encouragement and necessary facilities. The authors thank to Anonymous reviewers for valuable suggestions on the manuscript. Thankfulness is also due to the Curator of AMH-ARI, Pune for depositing holotype specimens and providing accession number. Shambhu Kumar is much appreciated to Science and Engineering Research Board (SERB), Department of Science and Technology (DST), Govt. of India, New Delhi for financial support (SB/YS/LS-288/2013). 


\section{References}

Cannon PF, Kirk PF. 2007 - Fungal Families of the World. Wallingford, UK, CAB International. pp. 456.

Castañeda RF, Kendrick B. 1990 - Conidial fungi from Cuba: II. University of Waterloo Biology Series. 33, 1- 62 .

Castañeda RF. 2005 - Metodología en el estudio de los hongos anamorfos. In: Anais do V Congresso Latino Americano de Micologia, Brasília, pp 182-183.

Christenhusz MJM, Byng, JW. 2016. The number of known plants species in the world and its annual increase. Phytotaxa 261 (3), 201-217. http://doi:10.11646/phytotaxa.261.3.1.

Ellis MB. 1971 - More Dematiaceous Hyphomycetes, Commonwealth Mycological Institute, Kew, England. pp 608.

Ellis MB. 1960 - Dematiaceous Hyphomycetes. I. Mycol. Pap. 76, 1-36.

Ellis, MB. 1976 - More Dematiaceous Hyphomycetes, Commonwealth Mycological Institute, Kew, England. pp 507.

Farr DF, Rossman AY. 2015 - Fungal Databases, Systematic Mycology and Microbiology Laboratory, ARS, USDA. Retrieved July 30, 2015, http://nt.ars-grin.gov/fungaldatabases/

Index Fungorum 2015 - Index Fungorum, accessed July 30, 2015, http://www.indexfungorum.org/ Jayasiri SC, Hyde KD, Ariyawansa HA, Bhat J, Buyck B, Cai L, Dai YC, Abd-Elsalam KA, Ertz D, Hidayat I, Jeewon R, Jones EBG, Bahkali AH, Karunarathna SC, Liu JK, Luangsa-ard JJ, Lumbsch HT, Maharachchikumbura SSN, McKenzie EHC, Moncalvo, JM, GhobadNejhad M, Nilsson H, Pang KA, Pereira OL, Phillips AJL, Raspé O, Rollins AW, Romero AI, Etayo J, Selçuk F, Stephenson SL, Suetrong S, Taylor JE, Tsui CKM, Vizzini A, Abdel-Wahab MA, Wen TC, Boonmee S, Dai DQ, Daranagama DA, Dissanayake AJ, Ekanayaka AH, Fryar SC, Hongsanan S, Jayawardena RS, Li WJ, Perera RH, Phookamsak R, de Silva NI, Thambugala KM, Tian Q, Wijayawardene NN, Zhao RL, Zhao Q, Kang JC, Promputtha I. 2015 - The Faces of Fungi database: fungal names linked with morphology, phylogeny and human impacts. Fungal Diversity 74(1), 3-18. http://doi:10.1007/s13225015-0351-8

Kirk PF, Cannon PF, Minter DW, Stalpers JA. 2008 - Dictionary of the Fungi. 10th ed. Wallingford, UK: CAB International. pp 711.

Murali TS, Suryanarayanan TS, Venkatesan G. 2007 - Fungal endophyte communities in two tropical forests of southern India: diversity and host affiliation. Mycol. Progress 6, 191199. http://doi:10.1007/s11557-007-0540-2

MycoBank. 2015 - MycoBank (Fungal databases nomenclature and species banks), accessed July 30, 2015, http://www.mycobank.org

Prakash A, Singh KK. 2001 - Observation on some threatened plants and their conservation in Rajaji National Park, Uttaranchal, India. Journal of Economic and Taxonomic botany 25 (2), 363-366.

Rajasekharan PE, Ganeshan S. 2002- Conservation of medicinal plant biodiversity Journal of Medicinal Aromatic Plant Sciences 24, 132-147.

Seifert KA, Morgan-Jones G, Gams W, Kendrick WB. 2011 - The Genera of Hyphomycetes. CBS Biodiversity Series no. 9. Utrecht: CBS-KNAW Fungal Biodiversity Centre, The Netherland. pp 997.

Warrier PK, Nambiar VPK, Ramankutty C. 1996 - Indian Medicinal Plants. Orient Longman Ltd., Madras, Vol. 1-5. 